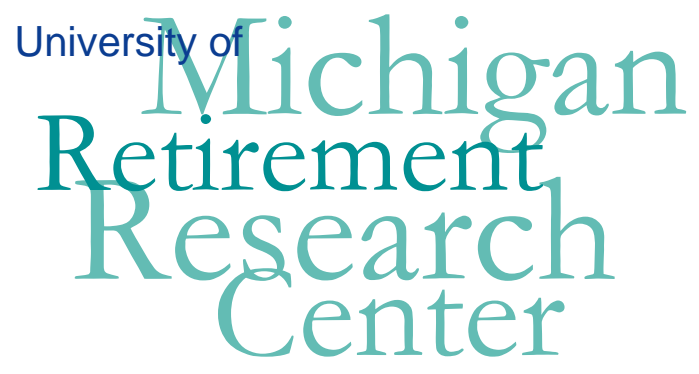

Working Paper

WP 2008-176

\title{
The Efficiency of Pension Plan Investment Menus: Investment Choices in Defined Contribution Pension Plans
}

Ning Tang and Olivia S. Mitchell

\begin{tabular}{|l|l|l|}
\hline $\mathrm{M}$ & $\mathrm{R}$ \\
\hline $\mathrm{R}$ & $\mathrm{C}$ & \\
\hline
\end{tabular}$\quad$ Project \#: UM08-20 


\title{
The Efficiency of Pension Plan Investment Menus: Investment Choices in Defined Contribution Pension Plans
}

\author{
Ning Tang \\ The Wharton School \\ Olivia S. Mitchell \\ The Wharton School
}

June 2008

\author{
Michigan Retirement Research Center \\ University of Michigan \\ P.O. Box 1248 \\ Ann Arbor, MI 48104 \\ http://www.mrrc.isr.umich.edu/
}

(734) 615-0422

\section{Acknowledgements}

This work was supported by a grant from the Social Security Administration through the Michigan Retirement Research Center (Grant \# 10-P-98362-5-04). The findings and conclusions expressed are solely those of the author and do not represent the views of the Social Security Administration, any agency of the Federal government, or the Michigan Retirement Research Center.

\section{Regents of the University of Michigan}

Julia Donovan Darrow, Ann Arbor; Laurence B. Deitch, Bingham Farms; Olivia P. Maynard, Goodrich; Rebecca McGowan, Ann Arbor; Andrea Fischer Newman, Ann Arbor; Andrew C. Richner, Grosse Pointe Park; S. Martin Taylor, Gross Pointe Farms; Katherine E. White, Ann Arbor; Mary Sue Coleman, ex officio 


\title{
The Efficiency of Pension Plan Investment Menus: Investment Choices in Defined Contribution Pension Plans
}

\author{
Ning Tang and Olivia S. Mitchell
}

\begin{abstract}
Few previous studies have explored whether defined contribution retirement saving plans offer sufficiently diversified investment menus, though it is likely that these menus significantly shape workers' accumulations of retirement wealth. This paper assesses the efficiency and performance of 401(k) investment options offered by a large group of US employers. We show that most plans are efficient compared to market benchmark indexes. Three performance measures underscore the fact that these plans tend to offer a sensible investment menu, when measured in terms of the menus' mean-variance efficiency, diversification, and participant utility. The key factor contributing to plan efficiency and performance has to do with the types of funds offered, rather than the total number of investment options provided.
\end{abstract}

\section{Authors’ Acknowledgements}

The opinions and conclusions expressed are solely those of the authors and do not represent the opinions or policy of SSA or any agency of the Federal Government. The research reported herein was performed pursuant to a grant from the U.S. Social Security Administration (SSA) to the Michigan Retirement Research Center, funded as part of the Retirement Research Consortium. This research also received support from the Pension Research Council at The Wharton School; the National Institutes of Health - National Institute on Aging, Grant number P30 AG12836; the Boettner Center for Pensions and Retirement Security at the University of Pennsylvania; and National Institutes of Health - National Institute of Child Health and Development Population Research Infrastructure Program R24 HD044964, all at the University of Pennsylvania. The authors thank Takeshi Yamaguchi for input and support; Raimond Maurer and his students at the University of Frankfurt, Finance Department, for helpful comments; and Steve Utkus, Gary Mottola, Theo Nijman, and Susan Thorp for very useful comments and suggestions. They are grateful to Vanguard for providing recordkeeping data under restricted assess conditions. Copyright 2008@ Pension Research Council of the Wharton School of the University of Pennsylvania. All rights reserved. 
Defined contribution (DC) plans have become a central financial investment vehicle for retirement saving; in the US, for instance, there were 42.4 million active participants involved in almost half a million 401(k) plans with assets totaling almost \$2 trillion (EBRI, 2005). Moreover, assets in 401(k) plans represent the sole source of retirement funding for a substantial fraction of 401(k) participants (Poterba, Venti and Wise 2007). There is a rich literature on participants' investment decisions in 401(k) plans, but much less attention has been paid to plan menus. ${ }^{1}$ This paper uses a rich new dataset on over 1,500 plans provided by Vanguard to study the characteristics and efficiency ${ }^{2}$ of $401(\mathrm{k})$ investment menus and investigate factors that affect plan performance.

Although plan sponsors have substantial freedom in setting up 401(k) investment menus, the 1974 Employee Retirement Income Security Act requires that they take responsibility for offering participants investment options with appropriate risk and return features, and monitoring the investment vehicles to make sure they continue to be appropriate. Thus it is useful to investigate the characteristics of various $401(\mathrm{k})$ plans, to evaluate whether they are satisfactorily offering employees such "appropriate" investment opportunities. It has also been noted that, over time, employers have added investment options to 401(k) plans. ${ }^{3}$ Therefore the question arises, as to whether adding more funds is necessarily better. To address this question, we explore factors that influence the efficiency of 401(k) plans, to see whether plan sponsors might enhance plan performance by adding investment choices. Additionally, recent proposals have suggested introducing individually-managed accounts into the U.S. Social Security system (Cogan and Mitchell, 2003). The present study on 401(k) plan menu design provides valuable experience for designing such a system.

\footnotetext{
${ }^{1}$ For example, Madrian, and Shea (2001) and Choi, Laibson, Madrian, and Metrick (2001) show that automatic enrollment increases $401(\mathrm{k})$ participation rates and participants tend to stay with the default contribution rate and fund allocation; Ameriks and Zeldes (2004) and Agnew, Balduzzi, and Sunden (2003) document inertia in asset allocations; Mitchell, Mottola, Utkus and Yamaguchi (2006) and Yamaguchi, Mitchell, Mottola, and Utkus (2006) study participant trading behavior and its impact on investment performance in DC plans; Benartzi and Thaler (2001) and Agnew (2002) show evidence of naïve allocation strategy among 401(k) participants; Karlsson, Massa, and Simonov (2007) suggest that investors choose assets as a function of the way they are represented in the menu; Liang and Weisbenner (2002) and Huberman and Sengmueller (2004) study participants investment behavior in company stock. Low financial literacy among 401(k) participants or average households is documented by Hancock (2002) and Lusardi and Mitchell (2007).

${ }^{2}$ A plan is efficient if its performance cannot be improved at a statistically significant level by adding more investment choices in the plan menu (Elton, Gruber and Blake, 2006).

${ }^{3}$ Brown, Liang, and Weisbernner (2007) show that the average number of options in 401(k) plans has increased from fewer than six options in 1993 to 14 options in 2002; Mitchell et al. (2006) show the average number of investment options has risen to about 17.
} 
To preview our findings, we show that most $401 \mathrm{k}$ plans examined are quite efficient, when we compare them to eight conventional benchmark indexes. Further, the plans examined perform quite well in terms of mean-variance efficiency, diversification, and participant welfare, in that they allow participants in these plans to invest optimally. We also show that, if participants were to follow a naïve " $1 / \mathrm{n}$ " allocation rule instead of the optimal strategy, this could entail a large loss. Most important to plan efficiency and performance is the choice of investment funds offered, rather than the number of options. As a result, more choice is not necessarily better when it comes to the 401(k) plan menu. Our results differ from two earlier studies, mainly because we have more recent data and use a larger sample of pension plans in the marketplace.

In what follows, we first offer a brief literature review followed by a data description. Next we assess plan efficiency and investigate how plan components, plan characteristics, and participant characteristics are linked to efficiency. Subsequently we compute performance measures of both tangency portfolios and alternative allocation strategies, and we investigate how plan performance varies with various characteristics. A final section concludes.

\section{Prior Literature}

The finance literature concludes that restricting investment opportunities tends to depress investment performance, making it less likely that an investor will achieve a market tangency portfolio with the highest Sharpe ratio. Losses due to investment restrictions in the defined contribution pension plan arena have been shown to be large by two studies of subsets of these plans. Elton, Gruber, and Blake (hereafter EGB, 2006) examined 417 401(k) plans surveyed by Moody's Investor Service in 2001; they estimated that participants in those inadequate plans would have $53 \%$ less terminal wealth compared to a market portfolio, over a 20 -year period. Angus, Brown, Smith, and Smith (hereafter ABSS, 2007) studied a subset of TIAA-CREF funds offered by some college-based 403(b) plans; for that subset, they claimed that a participant in these plans might lose more than half of terminal wealth over a 40-year period, compared to an expanded menu. Nevertheless, in light of the fact that plan sponsors have dramatically liberalized the investment menus offered in the 401(k) environment, it is important to assess their performance more generally and in a more representative and recent sample. Therefore, in what follows, we focus mainly on $401(\mathrm{k})$ plans to determine whether they offer efficient investment 
menus in the current environment, and to assess how large any economic and welfare losses might be in such plans due to investment restrictions.

It might be anticipated that the more investment choices offered in a 401(k) plan, the more diversified the investment options would be; if this were true, participants with larger menus should be able to do better by electing investment portfolios close to the market tangency portfolio. Yet most 401(k) plan investment menus involve only mutual funds, which are funds of many assets, so it should be possible to achieve the desired diversification level with only a few mutual funds. And if plan sponsors recognize that adding more options could be detrimental, they might instead wish to focus on a few selected funds instead of adding more options. ${ }^{4}$ In fact, a recent study by Brown, Liang, and Weisbenner (2007) suggests that when plan sponsors have added investment options to their plan menus in the past, they have tended to add high-cost actively managed equity funds instead of low-cost equity index funds. This may confuse participants if they spread their investments across the menu in a " $1 / \mathrm{n}$ " strategy (Benartzi and Thaler, 2001; Agnew, 2002). ${ }^{5}$ For this reason, adding menu choices might hurt portfolio performance if participant assets invested in index funds falls as the number of funds rises (Brown et al., 2007). Another previous analysis suggests that participants suffer from "choice overload" in 401(k) plans: Iyengar, Huberman and Jiang (2004) find a drop in plan participation as the number of fund options rises. "Information overload" is mentioned by Agnew and Szykman (2005) as the number of investment choices rises and choices become more similar; participants tend to become less satisfied and are hence more likely to choose an employerselected default, as they "choose not to choose."

In order for plan sponsors to design the optimal investment menu for 401(k) plan participants, we deem it important to differentiate two sources of investment opportunity restriction: on the one hand, the number of fund options provided, and on the other, the performance of options made available. In what follows, we conduct such an evaluation. We further assess what a hypothetical participant could achieve if he were to allocate his assets

\footnotetext{
${ }^{4}$ While plan sponsors may add risk-free funds to satisfy different risk preference levels (e.g. money market funds), this is not our focus here. Rather we explore the effect of the number of risky funds (equity funds, bond funds, balanced funds and company stock) on portfolio performance. Participants can then weight their investments between the risky and the risk-free funds according to their risk preferences.

${ }^{5}$ Huberman and Jiang (2006) report a "conditional 1/n" heuristic among 401(k) participants, which they indicate arises when participants invest evenly across the funds they use, but their investments are not sensitive to plan options.
} 
optimally, given the menu offered, and then we compare how much he would lose if he were to follow the $1 / \mathrm{n}$ rule of thumb just mentioned.

\section{Data}

We are fortunate to have available for analysis a dataset provided by Vanguard, a major mutual fund family, collected from the 401(k) plans managed on behalf of a wide range of plan sponsors. This rich and diversified dataset contains detailed information on plan menus, employer characteristics, and participant characteristics. At year-end 2004, the files included 1,530 DC plans, most of which are 401(k) plans; from this set, we selected an analysis sample of 1,014 plans that have at least 60 monthly return observations for each fund in the plan.

For each plan under analysis, we have rich information at the plan and the participant level. Plan-level information includes the number and type of investment choices offered, ${ }^{6}$ total assets under management, the number of accounts, ${ }^{7}$ the source of contributions (employer or employee), and the monthly total return data for each fund (12/97 12/04 ). ${ }^{8}$ We also measure plan type which allows us to distinguish separately $401(\mathrm{k})$ plans in the for-profit sector, from 403(b) plans in the non-profit sector (and others). Participant information is available on $1,186,554$ active accounts ${ }^{9}$ including participant age, sex, plan tenure, non-retirement financial wealth, household income, ${ }^{10}$ homeownership status, and whether the participant has web access. $^{11}$

Summary statistics appear in Figure 1, showing the number of funds offered in the plan menus. There is a wide range in menu offered, from 3 to 59 funds, though most plans concentrate around the mean number of funds offered, 13. This mean number of funds offered is consistent with the 14 found by Brown et al. (using 2002 data; 2007); ${ }^{12}$ our sample median number of offerings of 12 is much above the eight in EGB's (2006) older dataset. ${ }^{13}$

Figure 1 here

\footnotetext{
${ }^{6}$ Both broad and detailed categories of fund type defined by Vanguard are displayed in Table 1.

${ }^{7}$ Each employee in a plan is assigned a unique account.

${ }^{8}$ In a few cases some funds have fewer than 85 months of return observations.

${ }^{9}$ They are active accounts over the 24-month window in year 2003 - 2004 with positive contributions.

${ }^{10}$ Data from IXI Corporation is used as a proxy to impute non-retirement household financial wealth. Household income is imputed by Claritas for 2003 using ZIP code of participants.

${ }^{11}$ Participants registered for web access to their accounts are defined as having web accessibility.

12 They follow roughly firms that had 11-k data during in 1998 over the period 1999-2002.

${ }^{13}$ They use data from $680401(\mathrm{k})$ plans in a 2001 survey of pension plans provided by Moody's Investor Service.
} 
To show plan diversity, Table 1 describes the percentage of plans offering different types of funds. It can be seen that plan offerings are quite diversified, since almost all types of funds appear in every plan: $98.9 \%$ of the plans offer money market funds, $97.4 \%$ have bond funds, $96.5 \%$ have balanced funds, and almost all offer equity funds. It is also worth noticing the high percentage of plans offering international funds $(93.2 \%)$ and low percentage of plans offering company stock options (11.2\%).

Table 1 here

Table 2 offers a closer look at investment choices in 401(k) investment menus. Equity funds dominate plan options with an average share of 56\%; the rest of the funds include (in decreasing order) balanced funds, bond funds, money market funds, and other funds. There is little variation in fund prevalence across plans, except for equity funds. About $10 \%$ of the plans have fewer than four equity funds while there are $10 \%$ of the plans have more 12 options. Thus this provides corroborating evidence that plan sponsors tend to add equity funds when they expand the menu.

Table 2 here

Next we ask what types of funds are included in larger 401(k) investment menus. As noted earlier, Brown et al. (2007) claim that as the menu expands, the fraction of equity options increases and most are actively managed instead of indexed equity funds. This can have potential cost consequences if the index funds are less expensive and outperform high-cost actively managed funds. Figure 2 displays what type of funds are prevalent, arrayed by the number of options. It is shown that the number of equity funds is higher in larger menus, while balanced funds, bond funds, and money market funds are relatively stable. Figure 3 explores these patterns in more detail. Here we see that, when the menu grows, actively managed (AM) funds are more prevalent than index funds; AM funds dominate index funds; and domestic equity dominates in both AM funds and index funds.

Figures 2 and 3 here

\section{Evaluating 401(k) Plan Efficiency}

Next we test whether the investment choices offered in DC plans are efficient; that is, we test whether one might improve the performance of the tangency portfolio (optimal linear 
combination) of funds held by a plan, by adding more investment choices currently not included in the plan menu.

Efficiency Test. To test the efficiency of 401(k) investment menu, we adopt the "intersection test" developed by DeRoon, Nijman and Werker (2001). Implementing the test requires constructing a set of investment choices sufficient to capture the return-risk characteristics of market investment portfolio. Following EGB (2006), we construct a "market benchmark" composed of eight commonly-accepted financial market indexes. Four are domestic equity indexes following the Fama-French classification, which include Russell 1000 growth, Russell 1000 value, Russell 2000 growth, and Russell 2000 value. ${ }^{14}$ Two domestic bond indexes include Lehman Aggregate and Credit Suisse First Boston High Yield. ${ }^{15}$ We use one international equity index MSCI EAFE and one international bond index JP Morgan Global Government Bond NonUS\$. Finally, the one-month T-bill is taken as risk-free interest rate. ${ }^{16}$ As only risky funds including equity funds, balanced funds, bond funds, and company stock are the focus of efficiency tests, we delete money market funds, investment contract funds and unfunded funds from the analysis sample. Brokerage option funds are also excluded as we cannot observe their returns (only $2.4 \%$ plans offer such funds).

We evaluate whether adding any of the eight market benchmark indexes to each plan's tangency portfolio of funds might significantly improve the portfolio return at a given level of risk (DeRoon et al. 2001; EGB 2006). Under this test, there are short sale constraints for both funds in a plan and market benchmark index. Specifically, for each plan, we run the regression: $r_{i, t}=\alpha_{i}+\beta_{i} R_{t}+\varepsilon_{i, t}$

where $r_{i, t}$ is the excess return of the ith benchmark index $(\mathrm{i}=1,2 \ldots 8), R_{t}$ refer to excess returns of subset of funds held by a plan where short-sale constraints are not binding, ${ }^{17}$ and $\alpha_{i}$ is the Jensen's alpha from regression on ith benchmark index.

\footnotetext{
${ }^{14}$ Russell 1000 growth, Russell 1000 value, Russell 2000 growth and Russell 2000 value respectively represent large-cap growth, large-cap value, small-cap growth and small-cap value US equity markets.

${ }^{15}$ Blake, Elton and Gruber (1993) suggest to including a high-yield bond index to capture differences in return across bond funds.

${ }^{16}$ All returns on mutual funds are computed after expenses and returns on eight benchmark indexes are before expenses. But expenses on mutual funds are low as expense ratios from Vanguard Group are very low. So we don't deduct expenses from benchmark indexes to avoid estimation error.

${ }^{17}$ We keep funds with positive weights in the tangency portfolio formed by the whole set of funds.
} 
Next, we must test if $\alpha_{i} \leq 0 \forall i$, for each plan. As short-sales are not allowed for market benchmark index, if none of the $\alpha_{i}$ is statistically significant positive, we could conclude that performance of funds under the plan, $R_{t}$, cannot be improved by holding a long position in any of the eight market benchmark indexes. The specific test statistic is:

$\xi=\min _{\{\alpha \leq 0\}}(\hat{\alpha}-\alpha)^{\prime} \operatorname{Var}[\hat{\alpha}]^{-1}(\hat{\alpha}-\alpha)$

where $\hat{\alpha}$ is an $8^{*} 1$ vector of estimated Jensen's alphas. For the critical value used in the test, we will adopt lower/upper bound suggested by Kodde and Palm (1986) and run 1000 simulations for critical values if the test statistic falls within the bounds.

Results. The analysis shows that 951 (94\%) plans out of the 1,014 plans are efficient compared to market benchmark indexes (by the DeRoon et al. 2001 criterion). This very high level of efficiency of 401(k) investment menus implies that, by choosing the optimal portfolio in the efficient plans, plan participants can achieve at least the same performance as they could in the capital market more generally. It is important to point out that even a plan with fewer than eight funds can still perform at least as efficient as the portfolio formed by eight market benchmark indexes. One explanation is that well-performing mutual funds can span a combination of two or more market benchmark indexes (EGB, 2006). Thus even with a handful of investment choices, participants will not suffer from menu restriction, as long as the choices offered are sensible ones. We explore this point further in next section.

The fact that the vast majority of the 401(k) plans examined is efficient differs from EGB (2006) who adopted the same intersection test and reported that only about half of their plans were efficient. Several factors may explain this difference. First, plans in the EGB sample are far less diversified than our sample. For example, referring to Table 1, only $71 \%$ plans in the EGB sample offered domestic bond funds, $81 \%$ plans had domestic mix (balanced) funds, $75 \%$ plans had international funds and $87 \%$ had interest-only (money market) funds. Second, our sample is more likely to offer bond funds ( $71 \%$ in EGB vs. $97 \%$ in our sample), which also contributes to improved plan efficiency. Third, our data are from plan offerings at the end of 2004 while EGB data are drawn from 2001. The recently rapid growth in mutual fund market is likely to enhance performance. 
Summary Statistics on Efficiency Characteristics. With our rich data on plan characteristics, we can further explore what characteristics contribute to plan efficiency. In particular, we seek to know whether simply adding more funds improves plan efficiency. First we study the mean values of different characteristics in efficient and inefficient plans respectively, and test whether there is a significant difference between them. A two sample t-test for unpaired data is adopted. There are three groups of characteristics under analysis: plan components, plan characteristics, and participant characteristics.

Table 3 shows the summary statistics. In terms of plan components, we are interested in the number of options and the availability of different types of funds, ${ }^{18}$ which are the two major sources of investment restrictions. We find that there is no significant difference in the number of menu choices offered between efficient and inefficient plans. In fact, inefficient plans even offer more choices than do the efficient ones, on average. Of course many other factors may play a role in producing such a pattern, so in the next section we will further examine how the number of funds influences plan efficiency in a multivariate context. Table 3 also shows that index bond funds are more prevalent in efficient plans, while index balanced funds and actively managed bond funds are less prevalent.

\section{Table 3 here}

In terms of plan characteristics, we seek to determine whether bigger plans attract more attention from plan sponsors and obtain a higher level of efficiency. Also scale economy effects may further motivate plan sponsors to provide efficient plans. Accordingly we evaluate two indicators of plan size, namely the number of accounts per plan, and total 401(k) plan assets. As shown in Table 3 there is little support for the hypothesis. We also seek to assess whether different types of plans might have different levels of efficiency, but we find, contrary to Angus, Brown et al. (2007), that all 403(b) plans in our sample are efficient. Last, we are interested in contribution source. For instance, participants may be more concerned about their own contributions and demand a higher level of plan efficiency than when contributions are entirely or partially the employer responsibility. Again, however, Table 3 suggests no significant difference in contribution sources between efficient and inefficient plans.

\footnotetext{
${ }^{18} \mathrm{We}$ do not consider here money market funds, investment contract funds, unfunded funds or brokerage funds as they are not included in the efficiency test.
} 
In terms of participant characteristics, we seek to explore what kinds of participants are more likely to have efficient plans. We examine age, sex, plan tenure, and financial sophistication proxies (non-retirement financial wealth, income, home ownership, and web accessibility). Results in Table 3 show that participants in efficient plans are older than those in inefficient plans, but there is little evidence of significant difference in other characteristics.

Multivariate Analysis. To show how plan and participant characteristics affect plan efficiency individually, we use a multivariate Probit regression of the following form:

$$
\text { Effn }=\alpha+\beta_{1} P L A N C O M P+\beta_{2} P L A N C H A R+\beta_{3} P R T C H A R+\varepsilon
$$

where Effn is dummy variable ( 1 if plan is efficient, and 0 if not), PLANCOMP, PLANCHAR, PRTCHAR are the same sets of factors in plan components, plan characteristics and participant characteristics respectively. We add "squared number of funds" to capture the potential nonlinear relationship between the number of options and plan efficiency. Total assets, number of accounts, non-retirement financial wealth, and household income are scaled to the log form in the regression.

The first column of Table 4 shows the results of the above regression. Consistent with our earlier tabulations, the number of funds provided has no significant relationship with plan efficiency. This is striking: simply adding more funds does not improve plan efficiency. As noted above, equity funds including both indexed and actively managed funds account for over half the menu choices; accordingly, the effects of those two types of funds on plan efficiency deserve attention. Table 4 shows that indexed domestic equity funds improve plan efficiency significantly, while actively managed domestic equity funds appear to reduce plan efficiency (though the effect is not statistically significant). Recall the previous finding that with an increase in total number of investment options, the number of actively managed domestic equity funds increases more rapidly than that of index funds. To this end, we confirm that plan sponsors that add actively managed domestic equity funds should not do so in the hopes of boosting plan efficiency. Also, index bond funds improve plan efficiency and index balanced funds reduce it at a statistically significant level. Other funds have no significant effects on plan efficiency.

\section{Table 4 here}

There is no evidence for a relationship between plan efficiency and attributions of plan or participants, except that 403(b) plans are more efficient than 401(k) plans. Recall that earlier we showed that participants in efficient plans are older than those in inefficient plans, but this 
relationship is not evident in the Probit regression in Table 4, after controlling for other factors. Thus we can conclude that older participants are more likely to have more favorable investment options whose effects are captured by fund availability variables, and thus are more likely to have efficient plans.

\section{Evidence on Plan Performance}

The intersection test just describes tells us whether a plan offers adequate investment choices, compared to the market benchmark index, but it does not provide a measure of how efficient or inefficient any given plan may be. Yet plan sponsors and policymakers need to know how plans are performing with a performance measure that captures factors key to participant decision-making. To further assess plan performance, we next evaluate three performance measures advocated by Calvet et al. (2006) that help indicate how effective the 401(k) plan menu is in shaping participant outcomes. First we use the plan-specific Sharpe ratio, which measures each plan's mean-variance efficiency. Second, we quantify each plan's idiosyncratic risk, which indicates risk that could be diversified away and which is not rewarded by return in a CAPM context. Third, we measure the welfare of investors in a plan menu, taking into account participants' risk preference levels.

Return Moments Estimation. In order to compute plan performance measures, we need to estimate a plan-specific mean and variance of returns. To do so we follow Calvet et al. (2006) and adopt the CAPM asset pricing model here and regress fund returns on three market indexes:

$$
R_{i t}=\beta_{i}^{1} M K T_{t}+\beta_{i}^{2} B O N D_{t}+\beta_{i}^{3} E A F E_{t}+\varepsilon_{i, t}
$$

where $R_{i, t}$ is the excess return for fund $\mathrm{i}$; MKT is the excess return for Russell 3000 (broad domestic equity market); BOND is the excess return for Lehman US aggregate (broad domestic bond market); EAFE is the excess return for MSCI EAFE (international equity market); and the time period is 12/97 12/04 (or less if not available for some funds). Using the estimated risk loading $\hat{\beta}_{i}^{1}, \hat{\beta}_{i}^{2}, \hat{\beta}_{i}^{3}$ from the regression above, we can estimate moments for each fund: $\hat{\mu}_{f}=\hat{\beta} \hat{\mu}, \hat{\Sigma}_{f}=\hat{\beta} \hat{\Sigma} \hat{\beta}^{\prime}+\hat{\Sigma}_{\text {idio }}$, where $\hat{\mu}_{f}$ is the vector of estimated mean excess return over all funds; $\hat{\Sigma}_{f}$ is the estimated variance-covariance matrix of excess returns over all funds; $\hat{\beta}$ is

the vector of three betas over all funds $\hat{\beta}=\left(\hat{b}_{1}, \ldots, \hat{b}_{i}\right)^{\prime}, \hat{b}_{i}=\left(\hat{\beta}_{i}^{1}, \hat{\beta}_{i}^{2}, \hat{\beta}_{i}^{3}\right) ; \hat{\mu}$ is the mean excess 
return over three benchmark funds, $\hat{\mu}=\left(\hat{\mu}_{M K T}, \hat{\mu}_{B O N D}, \hat{\mu}_{E A F E}\right)^{\prime} ; \hat{\Sigma}$ is the variance-covariance matrix of three benchmark funds; and $\hat{\Sigma}_{\text {idio }}$ is the estimated idiosyncratic risk of funds estimated from the variance-covariance matrix of regression residuals $\varepsilon_{i, t}$.

Then, based on the estimated mean and variance of returns over all funds, we can estimate moments of plans: $\hat{\mu}_{p}=\omega^{\prime} \hat{\mu}_{f}, \hat{\Sigma}_{p}=\omega^{\prime} \hat{\Sigma}_{f} \omega, \hat{\Sigma}_{\text {idio, } p}=\omega^{\prime} \hat{\Sigma}_{\text {idio }} \omega$, where $\omega$ is the weight vector over all funds in each plan.

Relative Sharpe Ratio Loss. The relative Sharpe ratio loss (RSRL) proposed by Calvet et al. (2006) compares the Sharpe ratio of a given portfolio with that of a benchmark portfolio, to measure the economic loss under a mean-variance framework. In our case, the portfolio to be measured is the tangency portfolio of funds under each plan. The benchmark portfolio is the tangency portfolio formed by the eight market benchmark indexes introduced above. Thus for portfolio $\mathrm{p}$, the relative Sharpe ratio loss is defined as:

$$
R S R L_{p}=1-\frac{S_{p}}{S_{B}}
$$

where $S_{p}=\frac{\hat{\mu}_{p}}{\hat{\Sigma}_{p}}$ is the Sharpe ratio of tangency portfolio of funds held under the plan; ${ }^{19}$ the moments of the plan are estimated by the CAPM asset pricing model discussed earlier; and $S_{B}$ is the Sharpe ratio of tangency portfolio of eight benchmark indexes used in the efficiency test. The moments of the eight indexes are also estimated using CAPM. From equation (5), we can see the lower the ratio, the closer the two Sharpe ratios; in other words, this implies the better the performance of the plan relative to the benchmark portfolio.

The first row of Table 5, Panel A, describes the distribution of relative Sharpe ratio losses of the tangency portfolio formed by available funds in each plan. Overall, we see that the 401(k) plans in our analysis sample perform very well, compared to the benchmark portfolio: the mean relative Sharpe ratio loss of 0.03 is quite low. In other words, the Sharpe ratio of the tangency portfolio of an average plan is $97 \%$ of that of the benchmark portfolio. Furthermore, plans do not vary much in terms of their relative Sharpe ratio loss. Even at the 90th percentile, the measure is

\footnotetext{
${ }^{19}$ Money market funds, investment contract funds, unfunded funds and brokerage option funds are excluded, as we consider only the performance of risky funds (equity funds, bond funds, balanced funds, and company stock). The same applies to the idiosyncratic risk share and utility loss measures discussed next.
} 
only 0.04 . Nevertheless, there are a few plans not performing very well which boosts the $99^{\text {th }}$ percentile of the measure to 0.66 .

\section{Table 5 here}

Figure 4 shows the average relative Sharpe ratio loss for plans arrayed by the number of funds they offer in their menus. Overall, the measure is low, indicative of good performance. Particularly when a plan has more than nine funds, the measure is stable and below 0.02. Adding more funds does not improve the Sharpe ratio much after a plan includes a certain number of funds. It is also of interest that some small plans with fewer than six funds have a relatively high loss (over 0.1), but other small plans, with only two or three funds, perform very well. Their RSRL measures are even lower than plans with 15 options. So we conclude that the number of options in the plan is not a determining factor of plan efficiency. Below we shall explore the relationship between number of options and plan performance in more detail.

Figure 4 here

Idiosyncratic Risk Share. Next we examine plans' idiosyncratic risk share, which represents the share of idiosyncratic risk out of total variance of a portfolio. Idiosyncratic risk is defined as the risk that can be diversified away and therefore it measures a portfolio's undiversified risk (Calvet et al. 2006). Specifically:

$$
I R S_{p}=\frac{\hat{\Sigma}_{i d i o, p}}{\hat{\Sigma}_{p}}
$$

where $\hat{\Sigma}_{\text {idio, } p}$ is the idiosyncratic risk of tangency portfolio of funds held by a plan, and $\hat{\Sigma}_{p}$ is the total risk of the tangency portfolio. So the lower the ratio, the better is the performance of a given plan.

The distribution of idiosyncratic risk share across our sample appears in second row of Table 5, Panel A. On average, the idiosyncratic risk is 0.03 . In other words, only $3 \%$ of the total variance of plan's tangency portfolio is not diversified away. Even at the $90^{\text {th }}$ percentile, the ratio is still below 0.08 , which indicates a high diversification level. It is interesting that a handful about $1 \%$ of the plans - does not perform well according to this measure, with an idiosyncratic risk share of over 0.21 .

Figure 5 displays the average idiosyncratic risk share for plans arrayed by number of funds, where we see a pattern consistent with that found in Figure 4. Undiversified risk is not 
reduced by merely adding more funds, since the measure is stable and very low for plans having over nine funds. Plans with two or three funds can still achieve a very high level of diversification, if they select the right mutual fund choices. The consistency between Figures 4 and 5 suggests that undiversification measured by idiosyncratic risk share is an important source of the economic loss measured by relative Sharpe ratio loss.

Figure 5 here

Participants' Welfare Losses from Inefficient Menus. Next we measure participants' potential welfare or utility loss from having been offered a menu that is less efficient than the benchmark portfolio. As the measure takes into account individual risk preferences, it is an indicator of how much utility the participant might lose due to having a restricted plan menu relative to the benchmark portfolio.

We assume an individual with infinite horizon and CRRA utility function: $E_{0} \sum_{t=0}^{\infty} \delta^{t} \frac{C_{t}^{1-\gamma}}{1-\gamma}$, where $\delta$ is a discount factor and $\gamma$ is the coefficient of relative risk aversion (Calvet et al. 2006). The individual invests in a risk-free asset with return $r_{f}$ and a risky asset with given Sharpe ratio. Then we compare utility from holding benchmark portfolio with Sharpe ratio $S_{B}$ with utility from holding actual portfolio with Sharpe ratio $S_{p}$, the utility loss is equivalent to a decrease in the risk-free interest rate of:

$$
U L_{p}=\frac{S_{B}^{2}-S_{p}^{2}}{2 \gamma}
$$

where $S_{p}$ in our analysis is the Sharpe ratio of the tangency portfolio of funds held by a plan, and $S_{B}$ is the Sharpe ratio of tangency portfolio by eight benchmark indexes.

For example, Row 5 in Table 5, Panel A shows the distribution of annualized utility loss with risk aversion $\gamma$ of 4 . The results indicate a remarkably low level of welfare loss resulting from restrictions on 401(k) plan portfolios. For instance by investing in 401(k) menus instead of investing in the market benchmark portfolio, participants will experience an average utility loss equivalent to a decrease in annual risk-free return of $0.57 \%$. We deem these utility loss measures modest. On the other hand, there are a few inefficient plans that produce substantial utility losses of up to $10.57 \%$ at the 99 th percentile. By increasing the risk aversion level from 2 to 6 , as shown from row 3 to row 7 in Table 5, Panel A, the utility loss decreases. 
Figure 6 shows the average annual utility loss at risk aversion level $\gamma$ of 4 for plans arrayed by number of funds. For plans with more than nine funds, the utility loss is low and remains at a stable level, indicating that adding more options above nine does not increase participant utility in our set of 401(k) plans. Plans with only two or three funds can also perform quite well in terms of utility loss measure. Such a pattern is similar to that shown in Figures 4 and 5, so risk-return optimization and plan diversification contribute to participants' utility gain. Utility losses at other risk preference levels show the same trend.

Figure 6 here

Before leaving the discussion of utility loss, it is useful to assess our results in a different way. Our data for performance measures is monthly total returns. We annualize the Sharpe ratio by multiplying a factor of $\sqrt{12}$ directly and report the annual utility loss in terms of the equivalent annual risk-free rate in Table 5. This methodology is only accurate if returns are assumed IID (independently and identically distributed). To allow for possible autocorrelation among returns, we compute SR (12) as the annualized Sharpe Ratio as follows (Lo 2002):

$$
S R(q)=\frac{q}{\sqrt{q+2 \sum_{k=1}^{q-1}(q-k) \rho_{k}}} S R
$$

where $\rho_{k}$ is the kth-order autocorrelation of returns; $\mathrm{q}$ is 12 in the case of annualization; SR is the Sharpe ratio on monthly basis; and SR (12) is the Sharpe Ratio on annual basis. ${ }^{20}$ The results produce an even lower level of utility loss than reported before (see Appendix Table 1), so we conclude that our welfare loss findings are robust.

Performance Measures vs. Efficiency Test. Next we compare the performance measures for efficient and inefficient plans. Results in Table 6 show that there is no significant difference in relative Sharpe ratio loss between efficient and inefficient plans. Efficient plans have a statistically significantly lower idiosyncratic risk shares and utility losses than inefficient ones, so efficient plans do perform better than inefficient plans. But since the difference is small, this suggests that even inefficient plans in our sample are not far from optimal. For example, the

\footnotetext{
${ }^{20}$ We replace the monthly mean $\hat{\mu}$ and variance $\hat{\Sigma}$ of benchmark indexes returns in CAPM model the previous analysis with the annual mean $12 \hat{\mu}$ and annual variance $\left(12+2 * \sum_{k=1}^{11}(12-k) \rho_{k}\right) \hat{\Sigma}$, and we follow the same method to estimate fund and plan moments; then the annual Sharpe ratio is the ratio of estimated annual return over estimated annual standard deviation.
} 
difference in utility loss between efficient and inefficient plans is only $0.26 \%$ annually (assuming $\gamma=4)$.

\section{Table 6 here}

Naïve Allocation Strategies. Thus far we have measured plan efficiency in view of the optimal fund choices on each plan's menu. Next we assess whether participants might do poorly if they are unable to pick the optimal portfolio, despite a good array of investment choices made available. For instance, Benartzi and Thaler (2001) and Agnew (2002) suggest that some participants may follow a naïve " $1 / \mathrm{n}$ " heuristic when they allocate their money across investment options available to them. For this reason we compute the performance measures of portfolios following such a naïve allocation strategy, to see how much participants might lose even when their plan is well-designed. To implement this we again compute relative Sharpe ratio losses, idiosyncratic risk shares, and welfare losses, but now the portfolio examined is formed by assigning equal weights to all funds in each plan, instead of a plan's tangency portfolio.

Performance measures under such a naïve allocation strategy are reported in Panel B of Table 5. Comparing Panel B versus the tangency portfolio results in Panel A, it is clear that participants' relative Sharpe ratio losses and utility losses increase substantially in this scenario. For instance, the mean value of relative Sharpe ratio loss increases from only 0.03 for tangency portfolio to 0.72 under naïve allocation; mean utility loss at risk preference level 4 increase to $10.98 \%$, which is almost 20 times of the same measure for tangency portfolio $(0.57 \%)$. What this means is that, in a given plan, sophisticated investors can construct a resilient portfolio, but investors in the same plan would lose a great deal by following a " $1 / \mathrm{n}$ " allocation. This underscores the importance of a plan sponsor selecting a sensible default investment choice for participants unwilling or unable to make informed investment decisions on their own. Further, if participants suffer "information overload" from larger plan menus (Agnew and Szykman, 2005), this makes it even more important for plan sponsors to offer efficient and simple defaults to help participants avoid losing investment strategies, especially when they consider expanding the menu.

Factors Contributing to Plan Performance. Most plans in our analysis sample offer quite efficient investment menus, but there are still a few plans that do not. So next we ask whether any systematic factors are associated with plan underperformance. To do this, we run three multivariate linear regressions, similar to the model used in previously, except that the dependent 
variables are now the relative Sharpe ratio loss, idiosyncratic risk share, and utility loss $(\gamma=4)$, respectively. The dependent variables of three regressions are economic or welfare loss, so a negative coefficient represents a positive effect on plan performance and vice versa.

Results appear in Table 4, columns (2)-(4). We find, first, that the number of funds on the menu is positively associated with plan performance, but the magnitude is very small, especially compared to the effect of other factors such as availability of certain funds. For example, for plans initially having 12 funds, adding 10 more funds decreases the relative Sharpe ratio loss by only 0.003 , which is much lower than the coefficient on availability of index and actively managed bond funds $(-0.13$ and -0.05$)$. The marginal benefit from adding more options is also decreasing, indicated by the concave relationship between the number of options and plan performance. Bond funds including both index fund and actively managed funds improve performance by all three measures. Having actively managed balanced funds, international equity funds, and company stock funds does not enhance plan performance. In sum, and consistent with our previous finding, simply adding more options does not improve plan performance significantly (there is a positive effect for the handful of funds having few options originally). Considering the economic cost of adding more funds and the potential loss participants bear from facing complicated menus, it may be more effective to devote most attention to fund selection to influence plan performance. In other words, it is more sensible to add funds that make the menu more efficient, than simply to make the menu longer.

We also find that plans where employers make contributions are less diversified than employee-contribution-only plans, indicated by a positive coefficient (0.01) on idiosyncratic risk share. This suggests that when the money comes from participants' own pockets, they may pay more attention and demand better plans. Participant web access is negatively associated with the relative Sharpe ratio loss and utility loss (-0.04 and -0.007); in other words, web-registered participants with online access are likely to have better performing plans. As web registration can be a proxy for participant financial sophistication and a positive attitude towards 401(k) investment, those people with web accessibility may demand and have plans with better performance. 


\section{Conclusions and Discussion}

Pension plan participants, plan sponsors, and policymakers require better information about what is included in plan menus, how well the menus are constructed, and what characteristics contribute to plan efficiency and performance. Our analysis of over 1,500 plans provided by Vanguard shows that the vast majority of plans is efficient compared to conventional market benchmark indexes. Our results differ from two prior studies insofar as we use more recent data and a much larger study sample. Further, the plans examined perform quite well in terms of mean-variance efficiency, diversification, and participant welfare, providing workers with the opportunity to invest optimally. We also show that, if participants were to follow a naïve " $1 / \mathrm{n}$ " allocation rule instead of the optimal strategy, this could entail a large loss. Most important to plan efficiency and performance is the particular set of investment funds offered; more choice is not necessarily better when it comes to the 401(k) plan menu.

In light of our findings, plan sponsors would do well to ask how they can design menu choices that are both simple and financially efficient that would benefit unsophisticated participants. For instance, the goal might be to focus on selecting or adding funds that improve plan efficiency, instead of simply expanding the menu which might even hurt performance. One option would be life cycle or target maturity date funds which diversify participants' portfolios across stocks, bonds, and cash, automatically decreasing investment risk levels with age (Viceira, 2007). Another choice might be to combine target maturity date funds and a safe fund, as recommended by Bodie and Treussard (2007). Future research will examine how effective realworld 401(k) plan participants are at actually availing themselves of the efficient investment menus offered to them. 


\section{References}

Agnew, Julie, Pierluigi Balduzzi, and Annika Sunden. 2003. "Portfolio Choice and Trading in a Large 401(k) Plan,” American Economic Review, 93(1): 193-215.

Agnew, Julie, 2002, "Inefficient Choices in 401(k) Plans: Evidence from Individual Level Data," Presented at the $4^{\text {th }}$ Annual Joint Conference for the Retirement Research Consortium “Directions for Social Security Reform.” May 2002, Washington, D.C.

Agnew, Julie R. and Lisa R. Szykman. 2005. "Asset Allocation and Information Overload: The Influence of Information Display, Asset Choice, and Investor Experience." Journal of Behavioral Finance, 6 (2): 57-70.

Ameriks, John and Stephen P. Zeldes. 2004. "How Do Household Portfolio Shares Vary with Age?" TIAA-CREF working paper.

Angus, John, William O. Brown, Janet Kiholm Smith, and Richard L. Smith. 2007. "What's in Your 403(b)? Academic Retirement Plans and the Costs of Underdiversification." forthcoming, Financial Management.

Benartzi, Shlomo and Richard H. Thaler. 2001. "Naïve Diversification Strategies in Defined Contribution Savings Plans.” American Economic Review, 91(1): 79-98.

Blake, Christopher R., Edwin J. Elton and Martin J. Gruber. 1993. "The Performance of Bond Mutual Funds.” Journal of Business, 66: 371-403.

Bodie, Zvi and Jonathan Treussard. 2007. "Making Investment Choices as Simple as Possible, but Not Simpler.” Financial Analysts Journal, 63 (3): 42-47.

Brown, Jeffrey R., Nellie Liang and Scott Weisbenner. 2007. "Individual Account Investment Options and Portfolio Choice: Behavioral Lessons from 401(k) Plans.” NBER Working Paper No. 13169.

Calvet, Laurent E., John Y. Campbell and Paolo Sodini. 2006. "Down or Out: Assessing the Welfare Costs of Household Investment Mistakes.” NBER Working Paper No. 12030.

Choi, James J., David Laibson, Brigitte Madrian and Andrew Metrick. 2001. "For Better or For Worse: Default Effects and 401(k) Savings Behavior," NBER Working Paper No. 8651.

Cogan, John F. and Mitchell Olivia S. 2003. "Perspectives from the President's Commission on Social Security Reform.” Journal of Economic Perspectives, 17(2): 149-172. 
DeRoon, Frans A., Theo E. Nijman and Bas J.M. Werker. 2001. "Testing for Mean-variance Spanning with Short Sales Constraints and Transaction Costs: The Case of Emerging Markets." Journal of Finance, 56(2): 721-742.

Employee Benefit Research Institute. 2005. "History of 401(k) Plans: An Update," Facts from EBRI, Washington, DC: EBRI.

Elton, Edwin J., Martin J. Gruber and Christopher R. Blake. 2006. "The Adequacy of Investment Choices Offered by 401K Plans.” Journal of Public Economics, 90(6-7): 1299-1314.

Hancock, John, 2002, Eighth Defined Contribution Plan Survey. John Hancock Financial Services, Boston: John Hancock.

Huberman, Gur and Paul Sengmueller. 2004. "Performance and Employer Stock in 401(k) Plans," Review of Finance, 8: 403-443.

Huberman, Gur and Wei Jiang. 2006. "Offering vs. Choices in 401(k) Plans: Equity Exposure and Number of Funds," Journal of Finance, XLI (2): 763-801.

Iyengar, Sheena S., Gur Huberman and Wei Jiang. 2004. "How Much Choice is Too Much? Contributions to 401(k) Retirement Plans." In Pension Design and Structure: New Lessons from Behavioral Finance, Olivia S. Mitchell and Stephen P. Utkus, eds. Oxford University Press, Oxford: 83-96.

Karlsson, Anders, Massimo Massa and Andrei Simonov. 2007. "Pension Portfolio Choice and Menu Exposure.” In Redefining Retirement: How Will Boomers Fare? Brigitte Madrian, Olivia S. Mitchell, and Beth J. Soldo, eds. Oxford: Oxford University Press: 248-270.

Kode, David A., and Franz C. Palm. 1986. "Wald Criteria for Jointly Testing Equality and Inequality Restrictions." Econometrica, 54, 1243-1248

Liang, Nellie and Scott Weisbenner. 2002. "Investor Behavior and the Purchase of Company Stock in 401(k) Plans - The Importance of Plan Design.” FEDS Working Paper No. FEDS2002-36; AFA 2003 Washington, DC Meetings.

Lo, Andrew W. 2002. "The Statistics of Sharpe Ratios.” Financial Analysts Journal 58(4): 3652.

Lusardi, Annamaria and Olivia S. Mitchell. 2007. "Baby Boomer Retirement Security: The Roles of Planning, Financial Literacy, and Housing Wealth.” Journal of Monetary Economics. 54(1) January: 205-224. 
Madrian, Brigitte C. and Dennis F. Shea. 2001. "The Power of Suggestion: Inertia in 401(k) Participation and Savings Behavior," Quarterly Journal of Economics, 116(4): 11491187.

Mitchell, Olivia S., Gary R. Mottola, Stephen P. Utkus, and Takeshi Yamaguchi. 2006. "The Inattentive Participant: Portfolio Trading Behavior in 401(k) Plans." Pension Research Council Working Paper No. 2006-05, The Wharton School.

Poterba, James, Steven Venti, and David Wise. 2007. "Rise of 401(k) Plans, Lifetime Earnings, and Wealth at Retirement.” NBER Working Paper No. 13091.

Viceira, Luis M.. 2007. "Life-Cycle Funds." Harvard Business School Working Paper.

Yamaguchi, Takeshi, Olivia S. Mitchell, Gary R. Mottola, and Stephen P. Utkus. 2006. "Winners and Losers: 401(k) Trading and Portfolio Performance." Pension Research Council Working Paper No. 2006-26. The Wharton School. 
Table 1: Percentage of Plans Offering Investment Options by Fund Type

\begin{tabular}{lclc} 
Broad category & \% of Plans offering & Detailed category & \% of Plans offering \\
\hline \multirow{2}{*}{ Money market funds } & \multirow{2}{*}{98.9} & Money market & 74.6 \\
& & Investment contract & 49.7 \\
\hline \multirow{2}{*}{ Bond funds } & \multirow{2}{*}{97.4} & Unfunded & 0.3 \\
& & Bonds & 97.4 \\
\hline \multirow{2}{*}{ Balanced funds } & \multirow{2}{*}{96.5} & Balanced & 96.5 \\
\hline \multirow{2}{*}{ Equity funds } & \multirow{2}{*}{99.9} & Aggressive growth & 81.3 \\
& & Growth and income & 99.9 \\
& & Growth & 95.7 \\
\multirow{2}{*}{ Other } & \multirow{2}{*}{12.9} & International & 93.2 \\
\hline
\end{tabular}

Notes: $\mathrm{N}=1,014$ plans as of $12 / 04$. Brokerage option refers to a plan option where employees may select their own stock investments.

\section{Table 2. Plan Composition by Fund Type}

\begin{tabular}{lcccccc}
\cline { 2 - 6 } & Mean & $\begin{array}{c}\text { 10th } \\
\text { Percentile }\end{array}$ & $\begin{array}{c}25 \text { th } \\
\text { Percentile }\end{array}$ & Median & $\begin{array}{c}75 \text { th } \\
\text { Percentile }\end{array}$ & $\begin{array}{c}90 \text { th } \\
\text { Percentile }\end{array}$ \\
\hline N Fund Options per plan & 13.46 & 8 & 10 & 12 & 16 & 19 \\
Money Market & 1.29 & 1 & 1 & 1 & 2 & 2 \\
Bond & 1.65 & 1 & 1 & 1 & 2 & 3 \\
Balanced & 2.77 & 1 & 1 & 2 & 5 & 5 \\
Equity & 7.60 & 4 & 5 & 7 & 9 & 12 \\
Other & 0.15 & 0 & 0 & 0 & 0 & 1 \\
\hline Share of Options in plan (\%) & & & & & & \\
Money Market & 10.53 & 5.56 & 7.14 & 9.45 & 12.50 & 18.18 \\
Bond & 12.26 & 6.25 & 7.69 & 11.11 & 15.38 & 21.43 \\
Balanced & 19.98 & 7.69 & 10.53 & 18.18 & 28.57 & 35.71 \\
Equity & 56.07 & 41.67 & 50.00 & 56.25 & 63.16 & 70.00 \\
Other & 1.17 & 0.00 & 0.00 & 0.00 & 0.00 & 5.88
\end{tabular}

Notes: See Table 1. The table displays the distribution of options offered in each plan. 
Table 3. Characteristics of Efficient and Inefficient Plans

\begin{tabular}{lccc}
\hline & Efficient & Inefficient & \\
& $(1)$ & $(2)$ & $(1)-(2)$ \\
\hline Plan Components & & & \\
N funds & 12.13 & 12.35 & -0.22 \\
Offers Index Blanced funds (1=Yes) & 0.12 & 0.22 & $-0.10 *$ \\
$\quad$ Actively Mgd Balanced funds & 0.93 & 0.90 & 0.03 \\
$\quad$ Index Bond funds & 0.82 & 0.62 & $0.20 * * *$ \\
$\quad$ Actively Mgd Bond funds & 0.45 & 0.57 & $-0.12 *$ \\
$\quad$ Index Domestic Equity funds & 0.99 & 0.97 & 0.03 \\
$\quad$ Actively Mgd Domestic Equity funds & 0.96 & 0.98 & -0.02 \\
$\quad$ Index Int'l Equity funds & 0.24 & 0.21 & 0.04 \\
$\quad$ Actively Mgd Int'l Equity funds & 0.84 & 0.87 & -0.03 \\
$\quad$ Company stock & 0.11 & 0.11 & 0.00 \\
\hline Plan Characteristics & & & \\
N accounts & 1221.34 & 1020.76 & 200.57 \\
Total assets (\$M) & 50.72 & 46.07 & 4.65 \\
Plan type: 401(k) (1=Yes) & 0.87 & 0.89 & -0.02 \\
$\quad 403(b)$ & 0.01 & 0.00 & $0.01 * * *$ \\
$\quad$ Other & 0.12 & 0.11 & 0.01 \\
Any employer contributions (1=Yes) & 0.95 & 0.94 & 0.02 \\
\hline Participant Char acteristics & & & \\
Age & 46.06 & 44.98 & $1.08 *$ \\
Male & 0.52 & 0.48 & 0.04 \\
Plan tenure (years) & 0.59 & 8.97 & 0.62 \\
Household income (\$000) & 89.89 & 87.46 & 2.44 \\
Non-retirement financial wealth (\$000) & 53.27 & 51.74 & 1.53 \\
Homeowner & 0.67 & 0.03 \\
Web access (1=Yes) & 0.47 & 0.00 \\
\hline
\end{tabular}

Notes: N= 951 efficient plans and 63 inefficient plans. Mean values appear in columns (1) and (2). The difference in characteristics between efficient and inefficient plans is tested by two sample t-test. *, **, *** denotes $10 \%, 5 \%, 1 \%$ significance level respectively. Funds analyzed include equity funds, bond funds, balanced funds, and company stock but exclude money market funds, investment contract funds, unfunded funds and brokerage option funds. 
Table 4. Plan and Participant Effects on Plan Efficiency and Performance

\begin{tabular}{|c|c|c|c|c|c|c|}
\hline \multirow[t]{4}{*}{ Dependent Variables } & \multirow[b]{3}{*}{ Mean } & \multicolumn{2}{|c|}{ Plan Efficiency (Y es=1) } & \multirow{2}{*}{$\begin{array}{c}\text { Rel. } \\
\text { Sharpe } \\
\text { Ratio Loss } \\
\text { Mean=0.03 } \\
\end{array}$} & \multirow{2}{*}{$\begin{array}{c}\text { Idio sync. } \\
\text { Risk Share } \\
\text { Mean=3.24\% }\end{array}$} & \multirow{3}{*}{$\begin{array}{c}\text { Utility Loss } \\
\text { Mean=0.57\% } \\
\text { OLS Coefficient }\end{array}$} \\
\hline & & \multicolumn{2}{|c|}{ Mean $=93.8 \%$} & & & \\
\hline & & Probit Coefficient & Marginal & OLS Coefficient & OLS Coefficient & \\
\hline & & $(1)$ & & $(2)$ & (3) & (4) \\
\hline $\mathrm{N}$ funds & 12 & -0.0264 & $-0.25 \%$ & $-0.0037 * * *$ & $-0.0034 * * *$ & $-0.0006 * * *$ \\
\hline $\mathrm{N}$ funds squared & 176 & 0.0003 & $0.06 \%$ & $0.0001 * * *$ & $0.0001 * * *$ & $0 * * *$ \\
\hline Offers In dexed Balanced funds $(1=$ Yes $)$ & 0.13 & $-0.3514 *$ & $-4.10 \%$ & 0.0043 & -0.0007 & 0.0008 \\
\hline Actively $\mathrm{Mgd}$ Balanced funds & 0.93 & 0.0817 & $0.81 \%$ & 0.0116 & $0.0091 * *$ & 0.0023 \\
\hline Index Bond funds & 0.81 & $0.6927 * * *$ & $9.34 \%$ & $-0.1277 * * *$ & $-0.0791 * * *$ & $-0.023 * * *$ \\
\hline Actively Mgd Bond funds & 0.46 & 0.0258 & $0.24 \%$ & $-0.0531 * * *$ & $-0.0077 * *$ & $-0.0086 * * *$ \\
\hline Index Domestic Equity funds & 0.99 & $0.9635 * *$ & $18.39 \%$ & 0.0077 & 0.0144 & 0.0004 \\
\hline Actively Mgd Domestic Equity funds & 0.97 & -0.3721 & $-2.59 \%$ & -0.0019 & 0.0078 & -0.0006 \\
\hline Index Int'1 Equity funds & 0.24 & 0.0865 & $0.78 \%$ & $0.0156 * *$ & 0.0053 & $0.0025 * *$ \\
\hline Actively Mgd Int'1 Equity funds & 0.84 & -0.2683 & $-2.15 \%$ & 0.005 & $0.0088 *$ & 0.0007 \\
\hline Company Stock & 0.11 & -0.2683 & $-2.99 \%$ & 0.0179 & $0.0068 *$ & $0.0029 *$ \\
\hline \multicolumn{7}{|l|}{ Plan Characteristics } \\
\hline Total ass ets $(\$ M)$ & 50.43 & 0.0861 & $1.18 \%$ & -0.0017 & -0.0009 & -0.0003 \\
\hline $\mathrm{N}$ accounts & 1208.87 & 0.016 & $0.22 \%$ & -0.0003 & -0.0015 & -0.0001 \\
\hline Plan type: $401(\mathrm{k})=$ ref $403(\mathrm{~b})$ plan $=1$ & $1.18 \%$ & $3.628 * * *$ & $4.74 \%$ & -0.0005 & -0.0013 & -0.0006 \\
\hline Other $=1$ & $11.93 \%$ & -0.084 & $-0.89 \%$ & 0.0023 & 0.0015 & 0.0004 \\
\hline Any ER Contrib =1 & $95.07 \%$ & 0.0172 & $0.16 \%$ & -0.0033 & $0.0109 * * *$ & -0.0006 \\
\hline \multicolumn{7}{|l|}{ Participant Characteristics } \\
\hline Age (years) & 46 & 0.0291 & $0.27 \%$ & 0.0001 & -0.0005 & 0 \\
\hline Male & 0.52 & 0.3334 & $3.18 \%$ & -0.011 & 0.0037 & -0.0016 \\
\hline Plan participant tenure (years) & 10 & -0.00109 & $-0.01 \%$ & 0.0008 & 0.0001 & 0.0001 \\
\hline Household income $(\$ 000)$ & 89.74 & 0.2523 & $0.11 \%$ & 0.013 & 0.0027 & 0.0021 \\
\hline Non-ret. financial wealth $(\$ 000)$ & 53.17 & 0.0381 & $0.20 \%$ & 0.0016 & 0.0001 & 0.0002 \\
\hline Homeowner & 0.7 & -0.0504 & $-0.46 \%$ & 0.0125 & 0.008 & 0.0016 \\
\hline Web access & 0.47 & -0.6259 & $-6.25 \%$ & $-0.042 * *$ & -0.0104 & $-0.007 * *$ \\
\hline $\mathrm{NObs}$ & & 1,014 & & 1014 & 1014 & 1014 \\
\hline$-2 \log \mathrm{L}$ or R-squared & & 427 & & 0.3 & 0.48 & 0.35 \\
\hline
\end{tabular}

Notes: See Table 1. In the regressions we use $\log$ (total assets), $\log$ (number of accounts), $\log$ (household income), and $\log$ (wealth) while unlogged mean values are reported here. Values of participant characteristics are planlevel means over all plan participants. The Probit model in Col. (1) uses a plan efficiency dummy; marginal effects from the Probit regression indicate the change in probability of the plan being efficient, given a one unit change in the number of funds, participant age and tenure; a $1 \%$ increase in total assets, number of accounts, household income, and wealth, and all dummy variables change from 0 to 1. Cols. 2-4 report OLS regression coefficients with dependent variables respectively the relative Sharpe ratio loss, idiosyncratic risk share, and utility loss (with $\gamma=4$ ). $*$, **, *** denotes $10 \%, 5 \%, 1 \%$ significance level respectively. Funds analyzed include equity funds, bond funds, balanced funds, and company stock but exclude money market funds, investment contract funds, unfunded funds and brokerage option 
Table 5. Distribution of Performance Measures

\begin{tabular}{|c|c|c|c|c|c|c|c|c|}
\hline \multicolumn{9}{|c|}{ Panel A. Tangency Portfolio } \\
\hline & Mean & $\begin{array}{c}1 \text { st } \\
\text { Percentile }\end{array}$ & $\begin{array}{c}10 \text { th } \\
\text { Percentile }\end{array}$ & $\begin{array}{c}25 \text { th } \\
\text { Percentile }\end{array}$ & Median & $\begin{array}{c}75 \text { th } \\
\text { Percentile }\end{array}$ & $\begin{array}{c}\text { 90th } \\
\text { Percentile }\end{array}$ & $\begin{array}{c}\text { 99th } \\
\text { Percentile }\end{array}$ \\
\hline Relative Sharpe ratio loss & 0.03 & 0.00 & 0.01 & 0.01 & 0.01 & 0.01 & 0.04 & 0.66 \\
\hline Idiosyncratic risk share & 0.03 & 0.01 & 0.01 & 0.02 & 0.02 & 0.02 & 0.08 & 0.21 \\
\hline Utility loss $(\gamma=2)$ & $1.15 \%$ & $0.12 \%$ & $0.30 \%$ & $0.39 \%$ & $0.40 \%$ & $0.43 \%$ & $2.06 \%$ & $21.14 \%$ \\
\hline Utility loss $(\gamma=3)$ & $0.77 \%$ & $0.08 \%$ & $0.20 \%$ & $0.26 \%$ & $0.27 \%$ & $0.29 \%$ & $1.37 \%$ & $14.09 \%$ \\
\hline Utility loss $(\gamma=4)$ & $0.57 \%$ & $0.06 \%$ & $0.15 \%$ & $0.19 \%$ & $0.20 \%$ & $0.21 \%$ & $1.03 \%$ & $10.57 \%$ \\
\hline Utility loss $(\gamma=5)$ & $0.46 \%$ & $0.05 \%$ & $0.12 \%$ & $0.15 \%$ & $0.16 \%$ & $0.17 \%$ & $0.82 \%$ & $8.46 \%$ \\
\hline Utility loss $(\gamma=6)$ & $0.38 \%$ & $0.04 \%$ & $0.10 \%$ & $0.13 \%$ & $0.13 \%$ & $0.14 \%$ & $0.69 \%$ & $7.05 \%$ \\
\hline \multicolumn{9}{|l|}{ Panel B. Naïve Allocation } \\
\hline & Mean & $\begin{array}{c}1 \text { st } \\
\text { Percentile }\end{array}$ & $\begin{array}{c}10 \text { th } \\
\text { Percentile }\end{array}$ & $\begin{array}{c}25 \text { th } \\
\text { Percentile }\end{array}$ & Median & $\begin{array}{c}75 \text { th } \\
\text { Percentile }\end{array}$ & $\begin{array}{c}\text { 90th } \\
\text { Percentile }\end{array}$ & $\begin{array}{c}\text { 99th } \\
\text { Percentile }\end{array}$ \\
\hline Relative Sharpe ratio loss & 0.72 & 0.62 & 0.67 & 0.70 & 0.73 & 0.74 & 0.76 & 0.79 \\
\hline Idiosyncratic risk share & 0.04 & 0.01 & 0.01 & 0.02 & 0.04 & 0.05 & 0.08 & 0.21 \\
\hline Utility loss $(\gamma=2)$ & $21.97 \%$ & $20.34 \%$ & $21.22 \%$ & $21.77 \%$ & $22.08 \%$ & $22.30 \%$ & $22.49 \%$ & $22.84 \%$ \\
\hline Utility loss $(\gamma=3)$ & $14.64 \%$ & $13.56 \%$ & $14.15 \%$ & $14.52 \%$ & $14.72 \%$ & $14.87 \%$ & $15.00 \%$ & $15.23 \%$ \\
\hline Utility loss $(\gamma=4)$ & $10.98 \%$ & $10.17 \%$ & $10.61 \%$ & $10.89 \%$ & $11.04 \%$ & $11.15 \%$ & $11.25 \%$ & $11.42 \%$ \\
\hline Utility loss $(\gamma=5)$ & $8.79 \%$ & $8.14 \%$ & $8.49 \%$ & $8.71 \%$ & $8.83 \%$ & $8.92 \%$ & $9.00 \%$ & $9.14 \%$ \\
\hline Utility loss $(\gamma=6)$ & $7.32 \%$ & $6.78 \%$ & $7.07 \%$ & $7.26 \%$ & $7.36 \%$ & $7.43 \%$ & $7.50 \%$ & $7.61 \%$ \\
\hline
\end{tabular}

Notes: See Table 1. Means and distributions for relative Sharpe ratio losses, idiosyncratic shares, and utility losses at preference levels from 2 to 6 are plan-level. Panel A shows the distribution of performance measures of tangency portfolios while Panel B shows performance metrics assuming a naive (1/n) allocation strategy. 
Table 6. Performance Measures for Efficient and Inefficient Plans

\begin{tabular}{|c|c|c|c|c|c|c|c|}
\hline & $\begin{array}{r}\text { Relative } \\
\text { Sharpe ratio } \\
\text { loss } \\
\end{array}$ & $\begin{array}{l}\text { Idiosyncratic } \\
\text { risk share }\end{array}$ & $\begin{array}{r}\text { Utility } \\
\text { loss } \\
(\gamma=2) \\
\end{array}$ & $\begin{array}{r}\text { Utility } \\
\text { loss } \\
(\gamma=3) \\
\end{array}$ & $\begin{array}{r}\text { Utility } \\
\text { loss } \\
(\gamma=4)\end{array}$ & $\begin{array}{r}\text { Utility } \\
\text { loss } \\
(\gamma=5)\end{array}$ & $\begin{array}{r}\text { Utility } \\
\text { loss } \\
(\gamma=6)\end{array}$ \\
\hline (1)Efficient & 0.03 & 0.03 & $1.12 \%$ & $0.75 \%$ & $0.56 \%$ & $0.45 \%$ & $0.37 \%$ \\
\hline (2)Inefficient & 0.04 & 0.05 & $1.63 \%$ & $1.09 \%$ & $0.81 \%$ & $0.65 \%$ & $0.54 \%$ \\
\hline$(1)-(2)$ & -0.01 & $-0.02 * * *$ & $-0.51 \% * * *$ & $-0.34 \% * * *$ & $-0.26 \% * * *$ & $-0.20 \% * * *$ & $-0.17 \% * * *$ \\
\hline
\end{tabular}

Notes: See Table 1. The Table reports mean values of our performance measures in efficient and inefficient plans, along with their difference. Significance is tested using a two sample $t$ test of unpaired data. *, **, *** denotes $10 \%$, $5 \%, 1 \%$ significance levels, respectively. 
Figure 1. Percentage of Plans by Number of Funds Offered

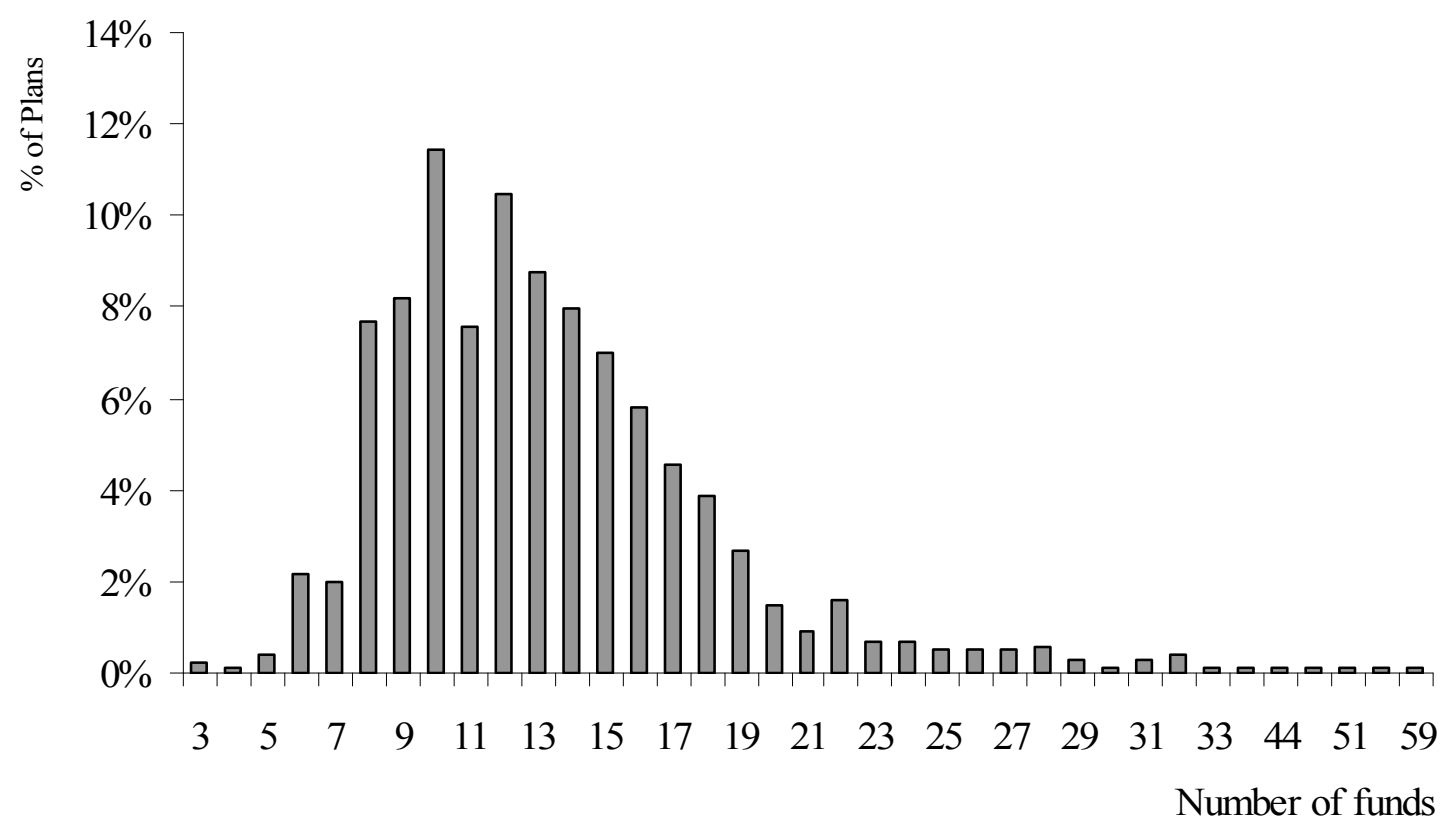

Notes: $N=1,014$ plans as of 12/04. Funds include money market funds, bond funds, balanced funds, equity funds, and other funds.

\section{Figure 2. Number of Funds Offered by Fund Type}

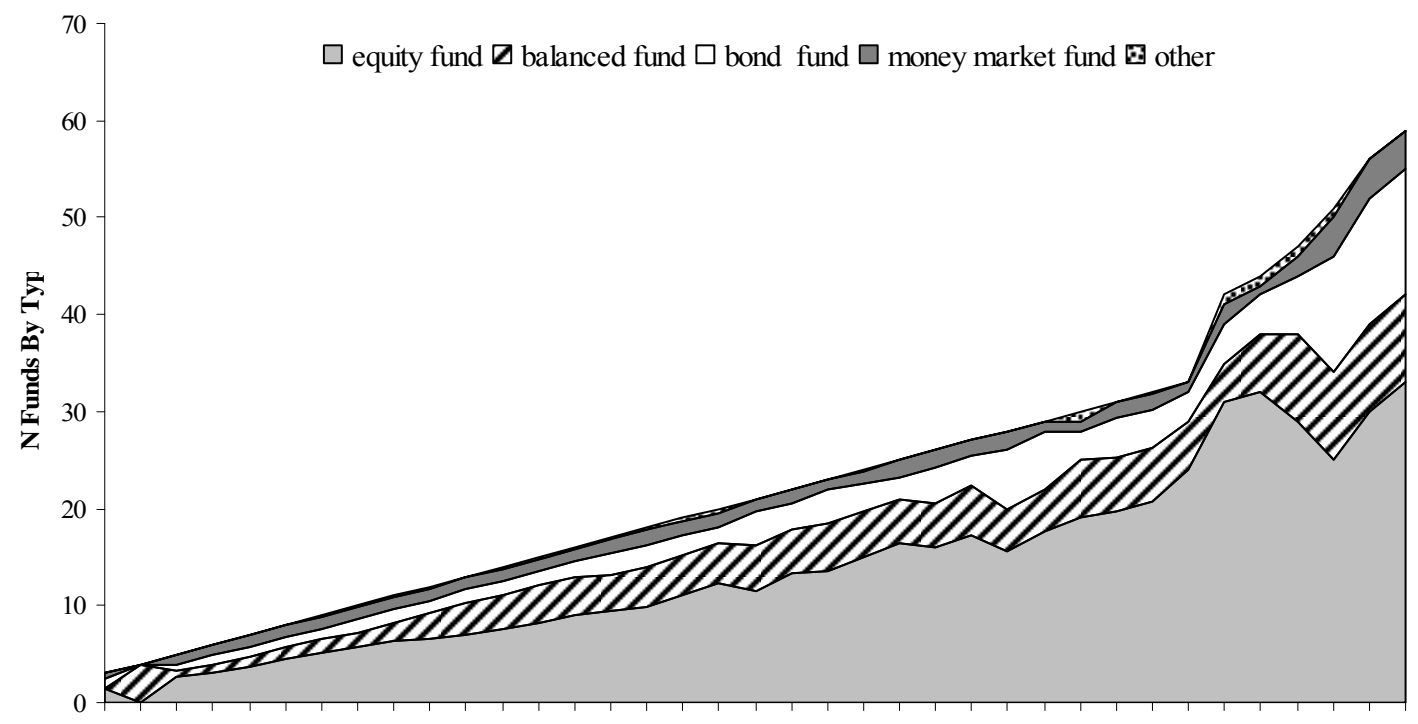

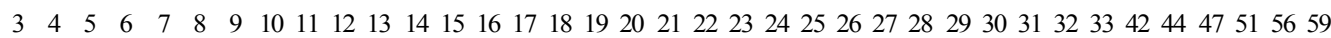

N Funds

Notes: See Figure 1. 


\section{Figure 3. Prevalence of Index Fund Offerings By Number of Funds Offered}

\section{A. Number of Index Funds By Type vs. Number of Funds Offered}

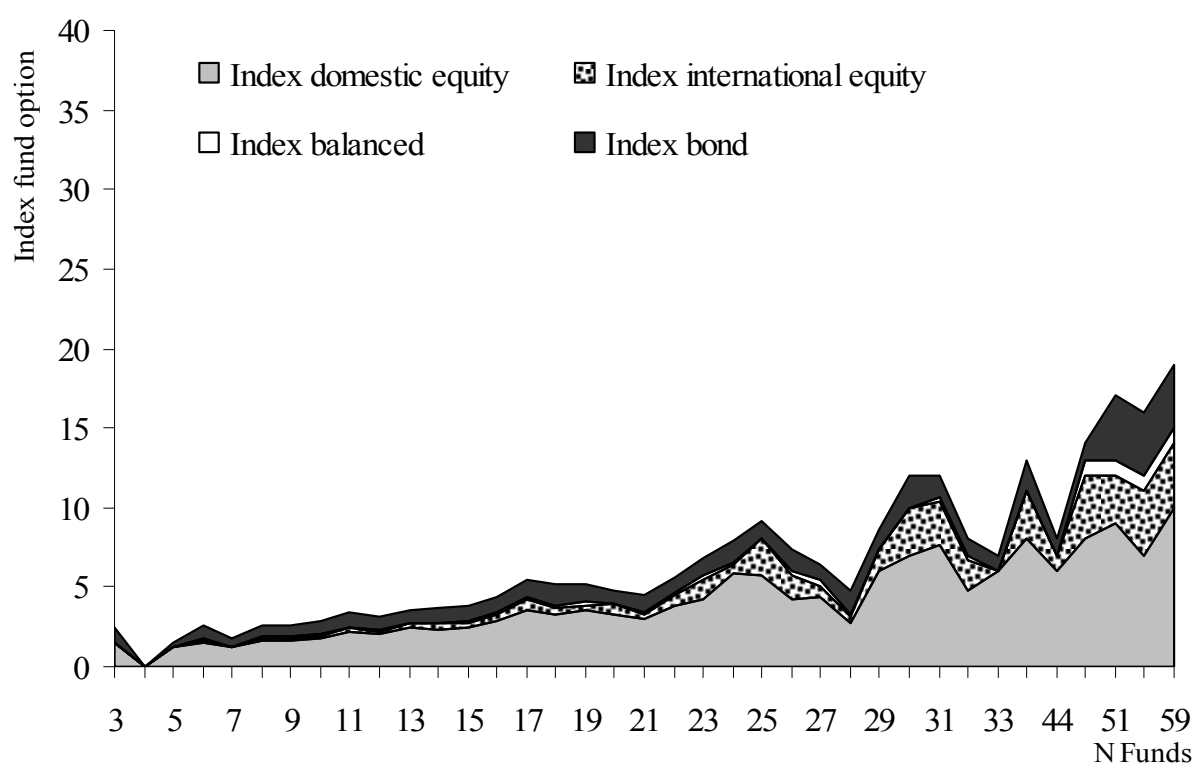

\section{B. Number of Actively Managed (AM) Index Funds By Type vs. Number of Funds}

Offered

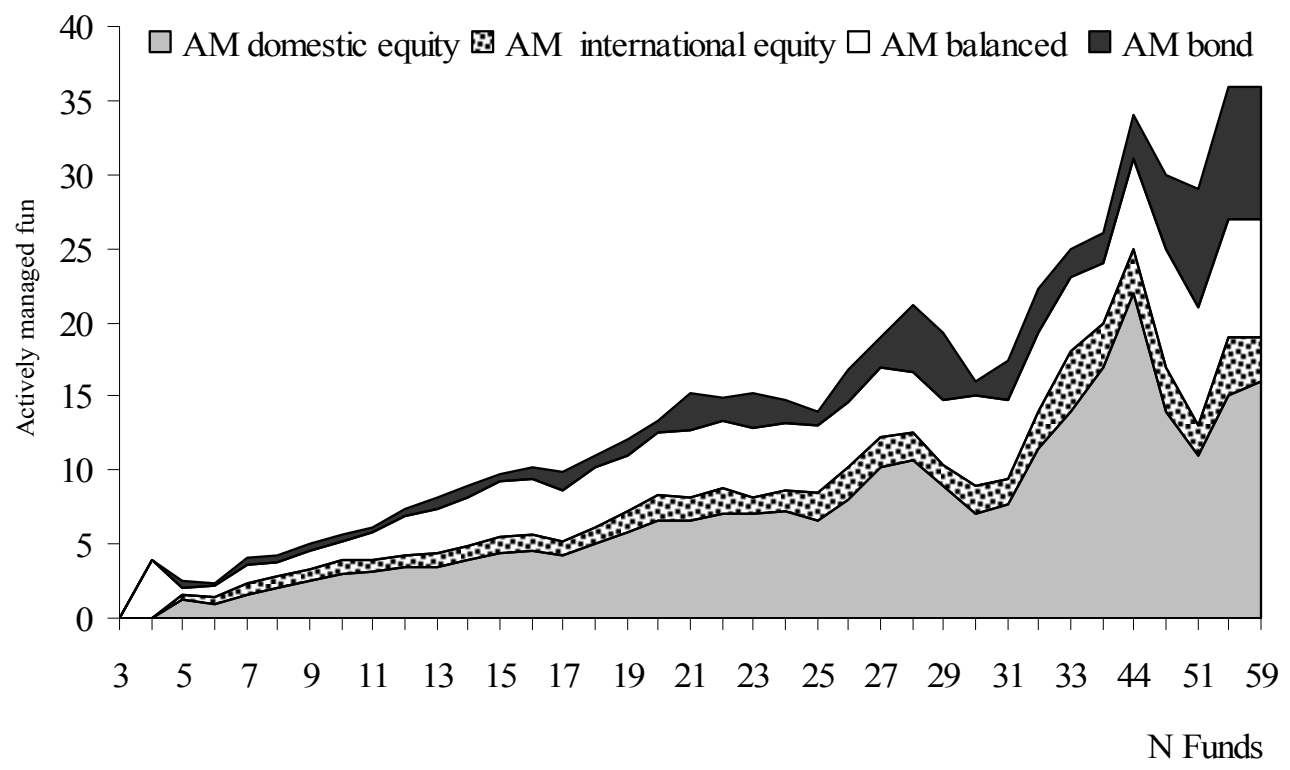

Notes: See Figure 1. In Panel A, index funds include index domestic equity, index international equity, index balanced, and index bond. In Panel B, actively managed (AM) funds include AM domestic equity, $\mathrm{AM}$ international equity, $\mathrm{AM}$ balanced, and $\mathrm{AM}$ bond funds. 
Figure 4. Relative Sharpe Ratio Loss vs Number of Funds Offered

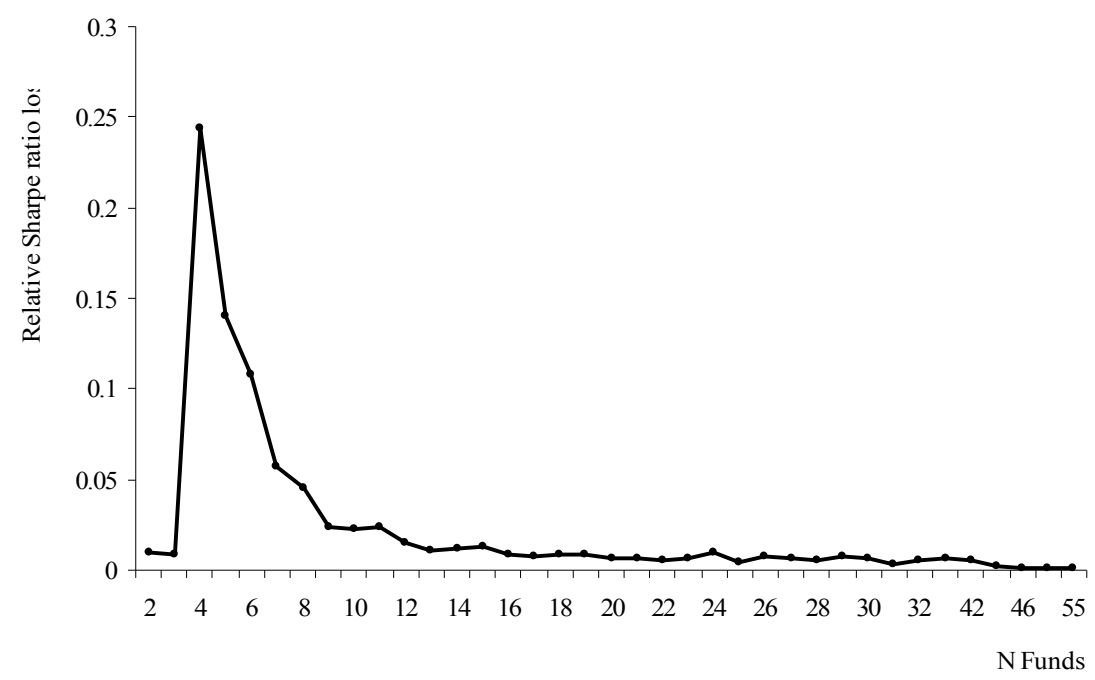

Notes: See Figure 1. Mean values of relative Sharpe ratio losses arrayed by the number of funds offered in each plan. Money market funds, investment contract funds, unfunded funds and brokerage option funds are excluded.

Figure 5. Idiosyncratic Risk Share vs Number of Funds Offered

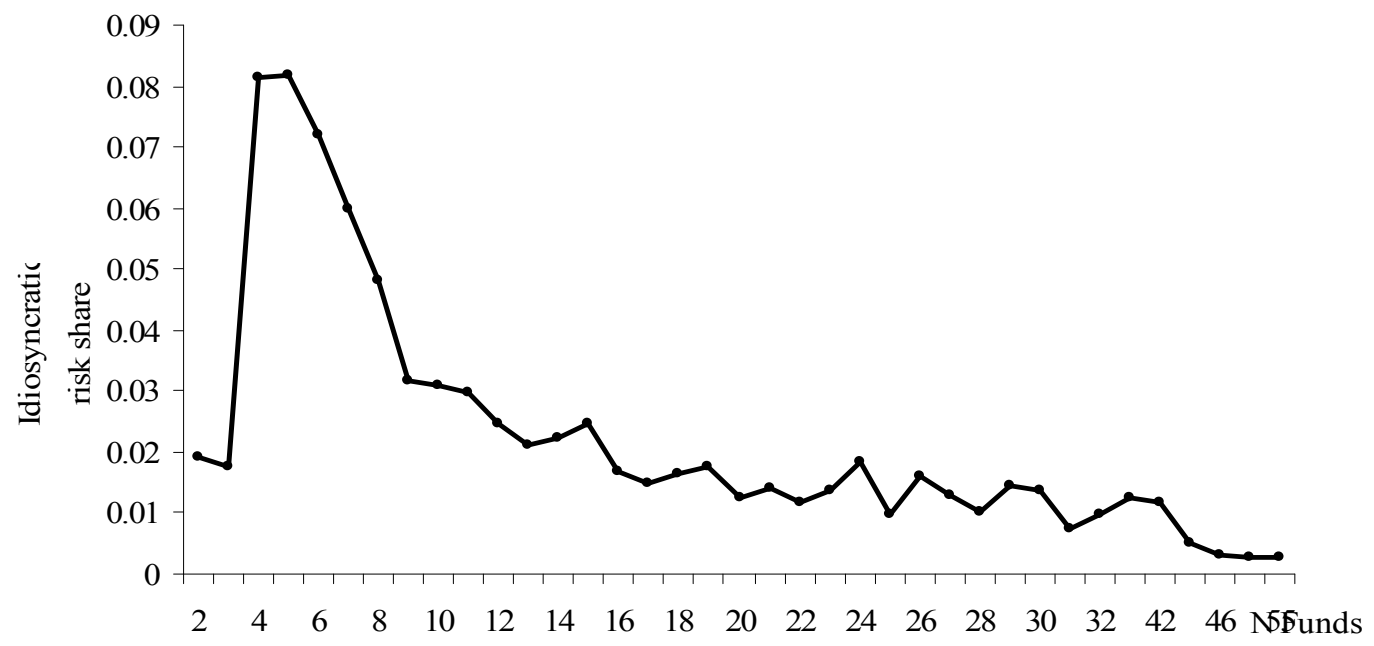

Notes: See Figure 1. The mean value of idiosyncratic risk share for plans is arrayed by the number of funds offered. Money market funds, investment contract funds, unfunded funds and brokerage option funds are excluded. 
Figure 6. Utility Loss vs Number of Funds Offered

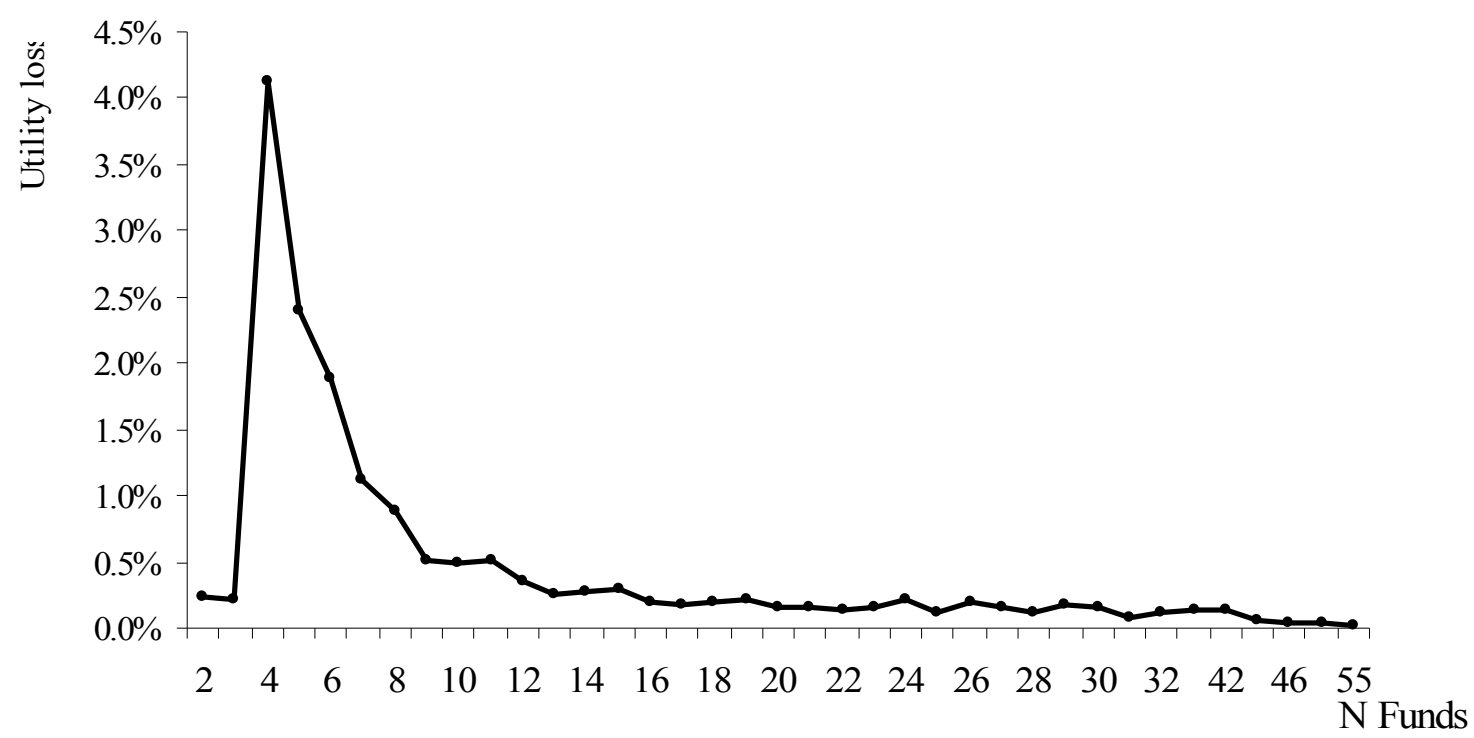

Notes: See Figure 1. The mean value of utility loss by plan (with $\gamma=4$ ) is arrayed by the number of funds offered. Money market funds, investment contract funds, unfunded funds and brokerage option funds are excluded. 


\section{Appendix Table. Distribution of Utility Loss}

\begin{tabular}{lcccccccc}
\hline & Mean & $\begin{array}{c}\text { 1st } \\
\text { Percentile }\end{array}$ & $\begin{array}{c}\text { 10th } \\
\text { Percentile }\end{array}$ & $\begin{array}{c}\text { 25th } \\
\text { Percentile }\end{array}$ & Median & $\begin{array}{c}\text { 75th } \\
\text { Percentile }\end{array}$ & $\begin{array}{c}\text { 90th } \\
\text { Percentile }\end{array}$ & $\begin{array}{c}\text { 99th } \\
\text { Percentile }\end{array}$ \\
\hline Utility loss $(\gamma=2)$ & $0.55 \%$ & $0.01 \%$ & $0.03 \%$ & $0.04 \%$ & $0.04 \%$ & $0.06 \%$ & $0.31 \%$ & $20.71 \%$ \\
Utility loss $(\gamma=3)$ & $0.36 \%$ & $0.01 \%$ & $0.02 \%$ & $0.02 \%$ & $0.03 \%$ & $0.04 \%$ & $0.21 \%$ & $13.80 \%$ \\
Utility loss $(\gamma=4)$ & $0.27 \%$ & $0.01 \%$ & $0.02 \%$ & $0.02 \%$ & $0.02 \%$ & $0.03 \%$ & $0.16 \%$ & $10.35 \%$ \\
Utility loss $(\gamma=5)$ & $0.22 \%$ & $0.01 \%$ & $0.01 \%$ & $0.01 \%$ & $0.02 \%$ & $0.02 \%$ & $0.12 \%$ & $8.28 \%$ \\
Utility loss $(\gamma=6)$ & $0.18 \%$ & $0.00 \%$ & $0.01 \%$ & $0.01 \%$ & $0.01 \%$ & $0.02 \%$ & $0.10 \%$ & $6.90 \%$ \\
\hline \hline
\end{tabular}

Note: Results use the annualization methodology of Lo (2002); see text. 